\title{
Iron Biogeochemistry in the Past, Present and Future - Endowed Biogeochemistry Lecture
}

\section{ANDREAS KAPPLER}

University of Tuebingen

Presenting Author: andreas.kappler@uni-tuebingen.de

Although it has been 200 years since our first microscopic view of iron-rich microbial mats, it's only now that we have begun to understand the mechanisms and environmental implications of biogeochemical iron cycling. On the one hand, microorganisms have been shown to oxidize reduced ferrous iron (Fe(II)) coupled to either photosynthesis, oxygen respiration or denitrification. On the other hand, we now know that microorganisms can make a living by reducing oxidized ferric iron (Fe(III)) coupled to oxidation of various organic compounds as well as dihydrogen $\left(\mathrm{H}_{2}\right)$, ammonium $\left(\mathrm{NH}_{4}^{+}\right)$, sulfide $\left(\mathrm{S}^{2-}\right)$ and even methane $\left(\mathrm{CH}_{4}\right)$.

In this presentation, I will share some case studies of how iron-metabolizing microorganisms shaped our Earth surface in the past, how they contribute to groundwater contamination in the present day, and how they are influencing our future climate. Specifically, the first part of my talk will show how ironmetabolizing microorganisms contributed to the deposition and to the characteristic alternating layering of silica and iron mineral bands in Precambrian Banded Iron Formations. In the second part, we will see how methane-oxidizing Fe(III)-reducing microorganisms can reductively dissolve arsenic-bearing $\mathrm{Fe}$ minerals and lead to groundwater contamination. Finally, in the third part I will explain how iron-metabolizing bacteria in permafrost soils and rice paddy soils contribute to greenhouse gas emissions $\left(\mathrm{CO}_{2}, \mathrm{CH}_{4}\right.$ and $\left.\mathrm{N}_{2} \mathrm{O}\right)$. 